Population Limitation in Arctic Ground Squirrels: Effects of Food and Predation

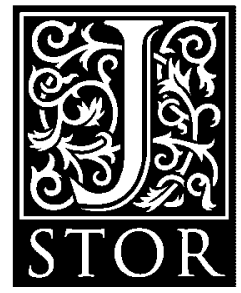

\author{
Anne H. Hubbs, Rudy Boonstra \\ Journal of Animal Ecology, Volume 66, Issue 4 (Jul., 1997), 527-541.
}

Stable URL:

http://links.jstor.org/sici?sici=0021-8790\%28199707\%2966\%3C527\%3APLIAGS\%3E2.0.CO\%3B2-D

Your use of the JSTOR archive indicates your acceptance of JSTOR's Terms and Conditions of Use, available at http://www.jstor.org/about/terms.html. JSTOR's Terms and Conditions of Use provides, in part, that unless you have obtained prior permission, you may not download an entire issue of a journal or multiple copies of articles, and you may use content in the JSTOR archive only for your personal, non-commercial use.

Each copy of any part of a JSTOR transmission must contain the same copyright notice that appears on the screen or printed page of such transmission.

Journal of Animal Ecology is published by British Ecological Society. Please contact the publisher for further permissions regarding the use of this work. Publisher contact information may be obtained at http://www.jstor.org/journals/briteco.html.

Journal of Animal Ecology

(C)1997 British Ecological Society

JSTOR and the JSTOR logo are trademarks of JSTOR, and are Registered in the U.S. Patent and Trademark Office. For more information on JSTOR contact jstor-info@umich.edu.

C2001 JSTOR

http://www.jstor.org/

Sat Dec 29 11:54:02 2001 
Journal of Animal Ecology 1997, 66, 527-541

\title{
Population limitation in Arctic ground squirrels: effects of food and predation
}

\author{
ANNE H. HUBBS* and RUDY BOONSTRA \\ Division of Life Sciences, Scarborough Campus, University of Toronto, Scarborough, Ontario, Canada MIC 1 A4
}

\begin{abstract}
Summary
1. We examined the relative importance of food and predators in limiting Arctic ground squirrel (Spermophilus parryii plesius Richardson) populations in the boreal forest of the southwestern Yukon during the peak and early decline of a snowshoe hare cycle (Lepus americanus Erxleben).

2. Squirrels were live-trapped from 1990 to 1992 on two control grids and three experimental treatments (food addition, mammalian and avian predator exclosure, and food addition plus mammalian predator exclosure). Adult squirrels were radiocollared on all areas in 1992.

3. Food addition increased densities $3-8$ times, generally increased reproductive traits (increased proportion of females lactating, doubled recruited litter sizes, resulted in earlier emergence of juveniles), increased immigration rates (but only in 1992), resulted in heavier females though not males at emergence in spring, and resulted in more rapid growth rates of juvenile males, but not of juvenile females. It had no effect on active season or overwinter survival rates.

4. Exclusion of predators had virtually no effect on any demographic variable measured, except for population densities in 1991 when they were approximately double those of the control populations.

5. Food addition plus exclusion of mammalian predators resulted in demographic changes that were comparable to those of food addition alone.

6. Thus, it appeared that food, not predators, limited ground squirrel populations at this stage of the hare cycle. However, independent of experimental treatment, active season survival of adult squirrels declined markedly from 1990 (high hare numbers) to 1992 (low hare numbers). Most of the radiocollared squirrels disappearing in 1992 were killed by predators and this was coincident with high densities of predators. In the predator exclosures, all predation mortalities resulted from avian predators which we could not exclude.

7. We conclude that both food and predators interact to limit Arctic ground squirrel populations during the peak and early decline of the hare cycle.

Key-words: boreal forest, population limitation, predator switching, population cycles, weather, Yukon.
\end{abstract}

Journal of Animal Ecology (1997) 66, 527-541

\section{Introduction}

The role of food (Boutin 1990; O’Donoghue \& Krebs 1992) and predation (Messier \& Crête 1985; Sih et al. 1985 ) in limiting the size of animal populations has been well documented. However, the precise interplay between these two critical factors has been addressed by relatively few studies (Watson \& Moss 1970;

(C) 1997 British Ecological Society
* Present address: Department of Zoology, University of Western Ontario, London, Ontario, Canada N6A 5B7.
McNamara \& Houston 1987; Mitchell, Arthur \& Farrow 1992; Sinclair \& Pech 1996). Population limitation is accomplished by those ecological processes that determine the equilibrium point of a population. In contrast, population regulation is accomplished by those ecological processes which are density-dependent and return a population to its equilibrium point (Sinclair 1989; Krebs 1995). Some ecological factors, such as food and predation, may both limit and regulate populations. Potentially, these two factors could operate additively, in which case the overall effect of 
both increasing food and decreasing predation would simply be the addition of the effect each of these factors manipulated separately. Alternatively, these two factors could operate interactively, in which case the overall effect of both increasing food and decreasing predation would be greater than the sum of their effects separately. The definitions of addivity or interaction are inherently decided by the statistical approaches chosen to analyse ecological processes and whether interactions are observed may be a function of the scale used. In terrestrial environments, many of the studies on mammals have focused almost exclusively on how food and predators interact to initiate or maintain low densities in mammal species that undergo periodic cyclic fluctuations in numbers (Taitt \& Krebs 1981; Taitt \& Krebs 1983; Ford \& Pitelka 1984; Boutin et al. 1986; Desy \& Batzli 1989). In our study, we examine how food and predation interplay to limit populations of a noncyclic species, the Arctic ground squirrel (Spermophilus parryii plesius).

The Arctic ground squirrel is the largest ground squirrel species in North America, lives throughout the northern boreal forest and Arctic tundra of Canada and Alaska, and hibernates from September through to mid-April (Banfield 1974). Previous studies have indicated that this species maintains stable populations over time (Carl 1971; Green 1977; Batzli \& Sobaski 1980), but whether food and predators both play a role in preserving this stability has not been examined. Instead, losses to starvation and predators have been reported anecdotally (Carl 1971; Green 1977). These latter two studies, both conducted in alpine tundra habitats, concluded that predation was relatively unimportant, and that food, spacing behaviour, and burrow availability collectively limited squirrel populations.

In the boreal forest of the southern Yukon the Arctic ground squirrel is a potential secondary food source for many predator species which eat primarily snowshoe hare (Lepus americanus) (coyote, Canis latrans Say; lynx, Lynx lynx L.; northern goshawk, Accipiter gentilis L.; Harlan's hawk, Buteo jamaicensis (Gmelin); great horned owl; Bubo virginianus (Gmelin)). Ground squirrel importance as prey may be expected to vary with the $8-11$ year snowshoe hare population cycle, becoming more important during the decline and low phases (Keith 1990). Erlien \& Tester (1984) reported declines of Franklin ground squirrels ( $S$. franklinii Sabine) shortly after hares declined in Minnesota, but they were not able to determine the cause. Similar declines in ground squirrel species following hare declines were seen in Alberta by Adamcik, Todd \& Keith (1979) and Keith \& Cary (1991), with the latter arguing that predators which normally preyed on hares switched to alternate prey such as ground squirrels when hares declined and thus these predators then caused subsequent decline of the squirrels.
Our objectives were to determine: (i) whether food, predators, or an interaction between food and predators limited populations of the Arctic ground squirrel in the boreal forest; and (ii) whether ground squirrel survival and density were affected by the snowshoe hare cycle. Our 3-year study coincided with the hare peak (1990 - spring estimates of $\left.1.48 \mathrm{ha}^{-1}\right)$ and the decline (1991-0.92 ha ${ }^{-1}$ and $1992-0.31 \mathrm{ha}^{-1}$ ) in the southern Yukon (Krebs et al. 1992; Boutin et al. 1995; Krebs et al. 1995). It was conducted as part of a longterm study (the Kluane Boreal Ecosystem Project, Krebs et al. 1995) designed to investigate community organization in the boreal forest.

\section{Experimental design}

Our study used three $1-\mathrm{km}^{2}$ experimental manipulations of the entire vertebrate community of the boreal forest. We chose to manipulate fewer large areas rather than more smaller ones because of the failure of most field experiments to address large-scale issues (Tilman 1989). Thus, it was not possible to replicate these experimental treatments because of their high cost and the labour involved in setting up and maintaining each one (Krebs et al. 1995). We did however, replicate the controls and thus have an estimate of the variability in non-manipulated populations.

1. Food Addition. Starting in $1988, \approx 300 \mathrm{~kg}$ of commercial rabbit chow (minimum $16 \%$ crude protein) was distributed every 5-6 days throughout the year to a 36 ha area of the boreal forest. Food was initially placed in culvert feeders, but grizzly bear (Ursus arctos L.) disturbance prompted distribution of food by fertilizer spreader along four 600-m long transects, each of which was separated by $183 \mathrm{~m}$ ('feeder rows') from 1989 onwards.

2. Predator Exclosure. In 1987 a 1-km², 8600-volt, 10strand electric fence $2 \cdot 2 \mathrm{~m}$ high was built to exclude large mammalian predators and it was effective from January 1989 onwards. In 1988, monofilament nylon lines (Blokpoel \& Tessier 1984) were strung $>2 \mathrm{~m}$ above the ground and at $0.2 \mathrm{~m}$ intervals over 9 ha of this fenced treatment to exclude avian predators. This section was located in one corner of mammalian predator exclosure. Frequent breakages during winter reduced monofilament coverage to about $80 \%$ of its initial area by 1990 .

3. Predator Exclosure + Food. In 1988 an electric fence similar to the Predator Exclosure was set up and within 36 ha of this fenced area food was added using the same protocol as that on the Food Addition treatment. Because of the winter breakage problems, no monofilament lines were strung on this area.

\section{Predictions}

1. If limitation by food occurs, then food addition should: (i) increase densities through enhanced repro- 
(C) 1997 British Ecological Society Journal of Animal Ecology, 66, 527-541 duction (litter size and percentage of lactating females) and survival during the active season (see Boutin 1990 for a review); and (ii) increase growth rates and body weights (Sullivan, Sullivan \& Krebs 1983; Dobson \& Kjelgaard 1985a; Wauters \& Dhondt 1989), which in turn should result in higher overwinter survival (Murie \& Boag 1984; Dobson \& Kjelgaard 1985b).

2. If limitation by predators occurs, then removal of predators should: (i) improve survival during the active season, resulting in higher densities; and (ii) have no effect on reproduction, growth rates, body weights, or overwinter survival (Marcström, Engren \& Kenward 1988; Marcström et al. 1989).

3. If limitation by both food and predators occurs, then the addition of food and the removal of predators should: (i) increase reproduction, growth rates, body weights, and overwinter survival; and (ii) increase survival during the active season, resulting in densities higher than that on either the Food Addition or the Predator Exclosure treatments.

\section{Study area}

Field sites were located along the Alaska Highway in the Shakwak Trench east of Kluane Lake in the southwest Yukon Territory, Canada $\left(61^{\circ} \mathrm{N}, 138^{\circ} \mathrm{W}\right)$ (Fig. 1). The area has five main habitat types: $32 \%$ closed canopy white spruce (Picea glauca Blake), 30\% open canopy spruce, $26 \%$ shrub (willows: Salix glauca L. and Salix alaxensis (Anderss.) Cov. and bog birch Betula glandulosa Raup.), 9\% meadow (predominantly grasses: Festuca altacia Trin. and Calamagrostis lapponica (Wahlenb.) Hartm.) and 3\% deciduous forest (Populus tremuloides Michx. and $P$. balsamifera L.) (C.J. Krebs \& A. Kenney, personal communication).

The region's climate is continental with a mean annual temperature of $0{ }^{\circ} \mathrm{C}$. Weather data collected at the Burwash Landing Climatological Station, $60 \mathrm{~km}$ west of the study area, provided an approximate measure of weather conditions in the study area. Snowfall was probably underestimated because the study area was slightly higher in elevation. The mean ambient winter temperature in September-April was lower in 1990-91 $\left(-12^{\circ} \mathrm{C} \pm 4 \quad[1 \mathrm{SE}]\right)$ than in 1991-92 $\left(-9^{\circ} \mathrm{C} \pm 3\right)$.

\section{Methods}

\section{LIVE TRAPPING}

Arctic ground squirrels were live-trapped from late April to late August, 1990-92 on two control and three experimental grids (Table 1). The percentage cover of the main habitat types in the study area was similar among areas as determined from aerial photographs (Foto Flight Co., Calgary, Alberta, Canada) (Table 1). Control A was $120 \mathrm{~m}$ from the Food Addition grid and Control B was $500 \mathrm{~m}$ from the Predator Exclosure + Food grid (Fig. 1). The trapping grids on the Food Addition and on the Predator Exclosure + Food treatments each overlapped two feeder rows. The Predator Exclosure + Food grid was $>80 \mathrm{~m}$ from the edge of the electric fence. The trapping grid within the Predator Exclosure treatment was also $>80 \mathrm{~m}$ from the edge of the electric fence and completely under the nylon monofilament lines, thus excluding both avian and large mammalian predators. In an attempt to partition out the impact of large mammalian predators from that of both avian and large mammalian predators, we established a new trapping grid in 1992 outside the area covered by monofilament but within the Predator Exclosure and called it the Mammalian Predator Exclosure.

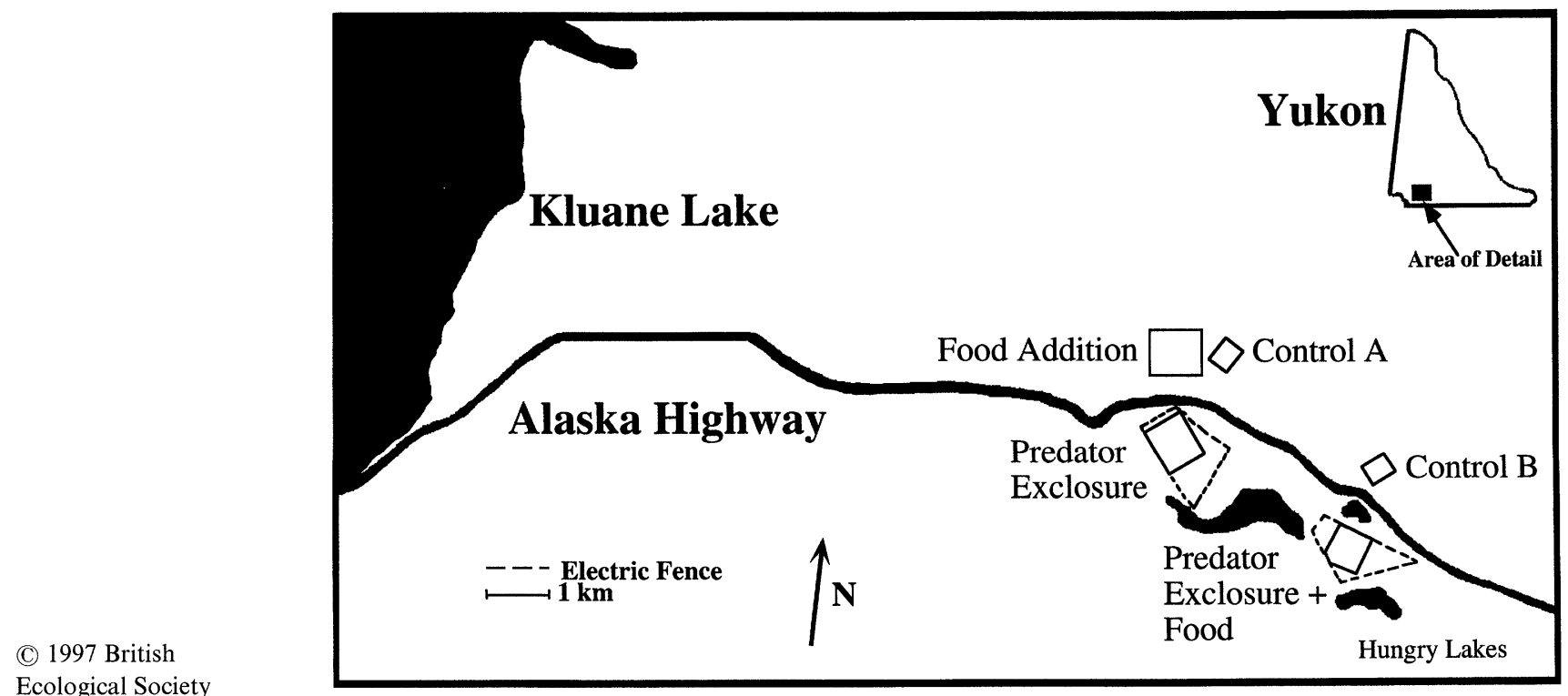

Fig. 1. Location of the study area in the south-western Yukon, Canada and the spatial arrangement of trapping grids and major experimental treatments. 
Effects of food and predation on squirrels

(C) 1997 British Ecological Society Journal of Animal Ecology, 66, 527-541

Table 1. Size and habitat classification of Arctic ground squirrel trapping grids at Kluane Lake, Yukon. The percentage of each habitat type on the grids was determined from aerial photographs

\begin{tabular}{|c|c|c|c|c|c|c|}
\hline \multirow[b]{2}{*}{ Grid } & \multirow[b]{2}{*}{$\begin{array}{l}\text { Size of grid } \\
\text { (ha) }\end{array}$} & \multicolumn{5}{|c|}{ Habitat classification $(\%)$} \\
\hline & & $\begin{array}{l}\text { Open } \\
\text { spruce }\end{array}$ & $\begin{array}{l}\text { Closed } \\
\text { spruce }\end{array}$ & Shrub & Meadow & $\begin{array}{l}\text { Deciduous } \\
\text { forest }\end{array}$ \\
\hline Control A & 10 & 50 & 0 & 31 & 13 & 6 \\
\hline Control B & 8 & 51 & 0 & 40 & 9 & 0 \\
\hline Predator Exclosure & 9 & 51 & 6 & 21 & 20 & 2 \\
\hline Mammalian Predator Enclosure & 7 & 52 & 1 & 39 & 8 & 0 \\
\hline Food Addition & 9 & 41 & 0 & 42 & 14 & 3 \\
\hline Predator Exclosure + Food & 8 & 48 & 0 & 36 & 16 & 0 \\
\hline
\end{tabular}

To obtain population density estimates, we trapped each grid four times on two consecutive days in the spring (late April - early June), early summer (July) and late summer (August) of each year and these periods coincided with adult emergence from hibernation, post-juvenile emergence from natal burrows, and pre-immergence into hibernacula, respectively. Single Tomahawk traps $(16.5 \times 16.5 \times 48.0 \mathrm{~cm}$ or $14 \times 14 \times 41 \mathrm{~cm}$; Tomahawk Live Trap Co., Tomahawk, Wisconsin, USA) baited with peanut butter were set outside burrow entrances. We placed two or three traps at sites with five or more burrow entrances or where more than one squirrel had been seen. All new squirrels were tagged in both ears and on each capture we recorded: tag number, location, mass ( $\pm 5 \mathrm{~g}$ with Pesola scales), sex, and breeding condition (males testes scrotal or abdominal; females lactating or not). Reproductive information from 1990 was unreliable because trappers were inexperienced and thus this data was ignored in our presentation.

Intensive trapping of juveniles (young-of-the-year) occurred from June to mid-July, 1991 and 1992, within 1-2 weeks of juveniles emerging from their natal burrows. During this period juveniles remained near their natal burrows and three techniques were used to locate these burrows: (i) a spool and line technique (Boonstra \& Craine 1986), (ii) walking surveys, and (iii) radiotelemetry. Because of problems with the spool and line technique (spool threads breaking), an average of 13 (range 2-25) adult breeding females were radiocollared (Model PD-2C, Holohil Systems Ltd, Woodlawn, Ontario, Canada) in 1992 on each grid prior to juvenile emergence. During the lactation period the radio locations of females before sunrise and during daylight hours were recorded. A burrow visited repeatedly by a lactating female was assumed to be her natal burrow. Once located, two or three Tomahawk traps and a wire-mesh multiple capture trap designed specifically to capture juveniles $(112 \times 20 \times 28 \mathrm{~cm}, 1 \mathrm{~cm}$ mesh - designed by Waterman 1986 and modified by J. Murie, personal communication) were set around the natal burrow entrance and prebaited with peanut butter for a 1-2 day habituation period. Trapping then occurred for
3-6 days on each grid. Juveniles were eartagged, weighed, and sexed.

\section{RADIOTELEMETRY}

Adult squirrels were radiocollared in 1992 to monitor survival. All males and females were collared on the Control grids (13 males and 20 females) and within the Predator and Mammalian Predator Exclosures (8 males and 16 females). Only females were collared on the Food Addition (25) and Predator Exclosure + Food (19) grids. We concentrated on females as their survival directly affects population growth through offspring production and survival. Squirrels were located an average of three times per week from late May to August except on the Predator and Mammalian Predator Exclosures where animals were located weekly. If a radiocollared squirrel was found dead or only its radio was found, the area was searched for evidence of mammalian or avian predation.

\section{STATISTICAL PROCEDURES}

Population size was estimated using the program CAPTURE (Otis et al. 1978). Estimates from the late summer were ignored when comparing densities among the treatments because some of the squirrels may have entered hibernation prior to the final trapping session (squirrels were found hibernating from mid-July onwards, T. Karels, personal communication). Estimates from the Mammalian Predator Exclosure were also ignored when comparing densities because trapping did not occur on this grid until 1992. Density estimates from spring and summer in 1990 from the Predator Exclosure + Food and from the Predator Exclosure, respectively, were excluded because trapping occurred during inclement weather causing severe underestimates.

We used log-linear models implemented in JMP (SAS Institute Inc. 1994) to compare changes in active season survival, in female reproduction, and in immigration with treatment and time. We used a logistic regression model implemented in S-PLUS (Statistical Sciences Inc. 1993) to determine which factors were 
531

A.H. Hubbs \&

R. Boonstra

(C) 1997 British

Ecological Society

Journal of Animal

Ecology, 66, 527-541 correlated with overwinter survival. This technique converted binary data from individuals (i.e. survived $=1$, disappeared $=0$ ) into probability values by fitting a logistic curve through available points (CluttonBrock, Albon \& Guinness 1987; Wauters \& Dhondt 1989). The parameters of the logistic model were estimated by maximum likelihood and the residual deviance provided an index of goodness-of-fit of a model including a particular set of parameters. We successively tested for the significance of interactions (second and first order) and then of main effects (backward selection approach) using likelihood-ratio tests (Agresti 1990). For radiotelemetry data, we compared survival amongst treatments using the Kaplan-Meier method (a non-parametric method; Pollock et al. 1989) and the Weibull regression method (a parametric method; Collett 1994) as calculated in Survival Analysis Tools (Abacus Concepts 1994).

Prior to ANOVAs, we used Cochran's test (Winer 1971), as recommended by Day \& Quinn (1989), to test for homogeneity of variance. We found that all continuous data satisfied this criterion. All ANOvAs, ANCOVAs and post-hoc tests (Tukey-Kramer) were performed with SuperANOva (Gagnon et al. 1990). Nonparametric tests were performed on all nominal data. All statistical tests were performed according to procedures in Zar (1984) and Sokal \& Rohlf (1981). Means are expressed as \pm 1 standard error (SE).

\section{Results}

\section{TRAPPABILITY}

We used two methods to estimate trappability: the first involved determining what proportion of radiocollared squirrels known to be alive on the grid were actually captured and the second involved the minimum trappability estimate given in Krebs \& Boonstra (1984) (this estimate is a conservative one which eliminates first and last times of capture, since animals are necessarily caught at these time). Of the adult animals radiocollared in 1992, 78\% of the females (all grids pooled, $n=45)$ and $50 \%(n=4)$ of the males were captured at each opportunity. The mean minimum trappability estimate (all grids pooled, the spring and early summer trapping sessions in 1991 and 1992 only were examined because of early entry into hibernation by some animals in the third session) for females was $81 \%$ (range for grids in which sample size was $>5$, $77-95 \%$ ) and for males was $71 \%$ (range for grids in which sample size was $>2,67-100 \%$ [few males were caught over more than two adjacent trapping periods, before they disappeared from the population], respectively. Thus, trappability estimates from these two methods were similar and, since they were generally high, we consider demographic information based on this trapping data reliable.

\section{POPULATION DENSITY}

Population densities on the Control grids averaged $1 \cdot 7 \pm 0 \cdot 3$ squirrels ha ${ }^{-1}$ (all trapping sessions pooled) from 1990 to 1992 (Control A, 1.33 $\pm 0 \cdot 21$; Control $\mathrm{B}, 2 \cdot 04 \pm 0 \cdot 50$ ) with about $65 \%$ as many squirrels on Control A as on Control B (Fig. 2). Densities on the Controls differed among years, particularly in summer, with half as many squirrels ha ${ }^{-1}$ in 1990 and 1992 (summer estimates on both Controls pooled: 1990 and 1992, 1.12 $\pm 0 \cdot 50)$ as in $1991(2 \cdot 90 \pm 1 \cdot 4)$. Density on the Predator Exclosure grid did not differ markedly from that on the Controls in 1990, was about twice that on Control $\mathrm{A}$ and $40 \%$ higher than that on Control B in 1991, and declined to values similar to that on the Controls in 1992 (Fig. 2). In 1990, densities on the Food Addition and the Predator Exclosure + Food grids were about 3-4 times that on the Control and Predator Exclosure grids. In 1991, densities on the Food Addition and the Predator Exclosure + Food grids were similar to each other and 3-8 times that on the Control grids and 2-3 times that on the Predator Exclosure grid. In 1992, densities on the Predator Exclosure + Food grid was about 7 12 times that on the Control and the Predator Exclosure grids and two times that on the Food Addition grid. Thus, food addition appeared solely responsible for the higher densities seen on the food treatments (independent of the absence of predators) in 1990 and 1991. Removal of predators had little impact on ground squirrel densities, except for a modest positive effect in 1991. Removal of both predators plus food

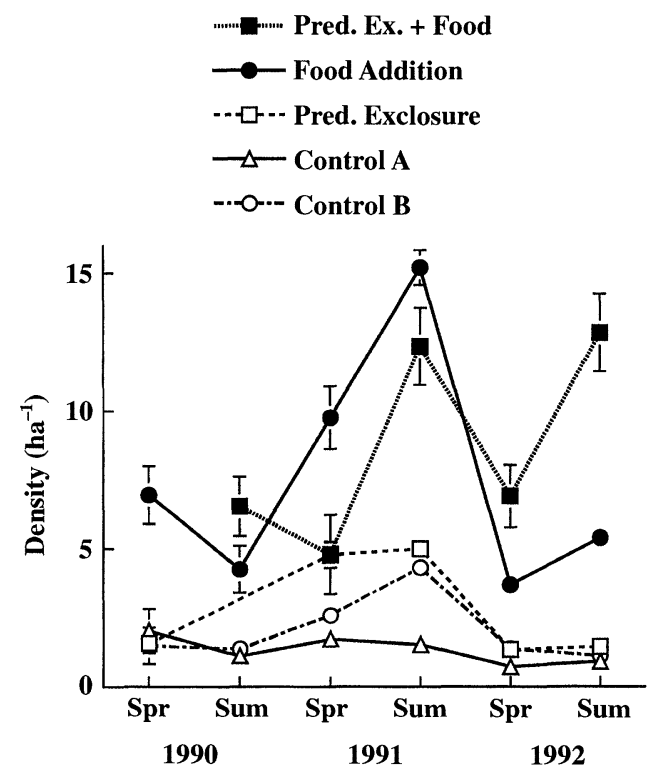

Fig. 2. Changes in population density ( \pm SE) of Arctic ground squirrels in spring and early summer from 1990 to 1992. Data points in which no confidence limits appear are those in which the mean and confidence limit were the same. Densities from spring and summer in 1990 from the Predator Exclosure + Food and from the Predator Exclosure, respectively, were excluded because trapping occurred during inclement weather causing severe underestimates. 
532

Effects of food and

predation on

squirrels addition resulted in a major increase in densities above that seen on all other grids, including the Food Addition grid, only in 1992. We believe this effect (see Discussion) was due not to the absence of predators on the Predator Exclosure + Food grid in 1992, but rather to the insufficiency of food on the Food grid during the critical spring period (see discussion below).

Habitat differences among grids may partially explain the observed treatment effects. Population estimates were therefore standardized according to the mean percentage of meadow habitat on all five grids $(14.4 \%$, Table 1$)$. The meadow habitat was selected as the standard because squirrels were relatively abundant in this habitat compared with shrub habitat and because the frequency of the most common habitat type, open spruce, was very similar on our grids (Table 1). We assumed that population change on the meadow portion of the grid was proportional to that observed on the whole grid. The results of this analysis did not differ from the above analysis and thus we conclude that habit differences did not account for the treatment effects we observed.

Densities changed markedly among years. From summer 1990 to spring 1991, all grids showed a modest increase, with numbers increasing $55 \%$ on Control A, $24 \%$ on Control B, $13 \%$ on the Food Addition, and $5 \%$ on the Predator Exclosure + Food (a value could not be obtained for the Predator Exclosure for reasons already given). From summer 1991 to spring 1992, all grids showed a drastic decline with numbers falling $53 \%$ on Control A, $67 \%$ on Control B, $74 \%$ on the Predator Exclosure, $76 \%$ on the Food Addition, and $44 \%$ on the Predator Exclosure + Food. Thus, the addition of food to the latter two grids did not prevent the overwinter decline in density. Clearly the absence of mammalian predators had little impact on this decline, as the Predator Exclosure experienced a decline similar to that on the Food Addition grid.

\section{SURVIVAL}

\section{During the active season (April-August)}

To determine whether years and treatments differed in survival over the active season, we calculated what proportion of squirrels present in spring within one year were still present in late summer of that year (either caught at that time or at some subsequent time). We assumed that squirrels which were not retrapped were dead unless they were males which disappeared during the period shortly after juvenile emergence (mid-June to mid-July in our study area) in which case they were assumed to have dispersed and still be alive (Lacey 1991). All females which disappeared during this period were considered dead (adult females show little dispersal once a maternal burrow has been established, and hence once an adult female disappears, she has probably died). Although this method underestimated the percentage of squirrels surviving by $35-39 \%$ relative to radiotelemetry data (see below), it provided a comparable relative index of survival. Since there was no significant interaction effect between treatment and year $\left(\chi^{2}=9 \cdot 65\right.$, d.f. $=8, P=0 \cdot 29$ ), we deleted the interaction term from the model and examined only the main effects. There were significant differences among years $\left(\chi^{2}=49 \cdot 44\right.$, d.f. $\left.=2, P=0.0001\right)$, with 1990 having significantly higher survival $(60 \%)$ than $1991(42 \%)$ or $1992(27 \%)$, which were statistically similar (Table 2). All grids showed this marked decline in active season survival from 1990 to 1992 , with that from the Controls being the most marked and falling about $48-56 \%$, that from the Predator Exclosure + Food falling about $46 \%$, and that from the Food Addition and the Predator Exclosure falling 18-23\% (though these latter two grids experienced relatively poor survival in 1990). There were also significant survival differences among treatments $\left(\chi^{2}=21 \cdot 44\right.$, d.f. $=4$, $P=0.0003)$, with the following rankings: Predator Exclosure + Food $>$ Predator Exclosure $=$ Food Addition $=$ Control $\mathrm{B}=$ Control A. Therefore, the exclusion of both predators and food addition improved survival over each of these treatments acting separately (neither of which were different from the Controls), but only in 1990 and 1991. The year with the lowest hare densities (1992) coincided with the lowest summer survival of ground squirrels on all grids independent of treatment.

We also obtained survival estimates based on radiotelemetry in 1992 which were not biased by the need to recapture squirrels in traps. We performed two analyses: the first examined whether adult females on the four treatments (Controls pooled, Predator Exclosure, Food Addition, and Predator Exclosure + Food Addition) had similar survival rates; and the second examined whether sex affected survival on the two treatments (Controls and Predator Exclosure) in which both adult males and females were radiocollared. There was no significant difference in survival of radiocollared females among the control and experimental grids in 1992 based on Kaplan-Meier estimates (a nonparametric method) of survival (Mantel-Cox logrank test, $\chi^{2}=2 \cdot 35$, d.f. $=3, P=0.50$ ), although survival curves (Fig. 3) appeared noticeably lower on the Controls. We also fit a Weibull regression model [a parametric method and more powerful - it assumes that the survival distribution is appropriate to the model and this was validated as the $\ln$ (cumulative hazard) against $\ln$ (time) plot was linear for this data], but again found no treatment effect $\left(\chi^{2}=6.09\right.$, d.f. $=3, P=0 \cdot 11)$. In the second Kaplan-Meier analysis, we again found no difference in survival of animals on the Controls vs. those on the Predator Exclosure plus Mammalian Predator Exclosure independent of whether the data was stratified by sex (Mantel-Cox logrank test, $\chi^{2}=2 \cdot 49, \quad$ d.f. $=1$, $P=0 \cdot 12)$ or pooled $\left(\chi^{2}=2 \cdot 56\right)$ (Fig. 4$)$. There were
Ecological Society Journal of Animal Ecology, 66, 527-541 
533

A.H. Hubbs \&

R. Boonstra

Table 2. Percentage of adult ground squirrels surviving during the active season (spring to summer) in 1990 (high numbers of hares) to 1992 (low numbers of hares) based on trapping data (sample sizes shown in parentheses)

\begin{tabular}{llll}
\hline \multicolumn{4}{l}{ Percentage surviving } \\
\cline { 2 - 4 } Grid & 1990 & 1991 & 1992 \\
\hline Control A & $64 \cdot 3(14)$ & $25 \cdot 8(31)$ & $16 \cdot 7(12)$ \\
Control B & $76 \cdot 9(13)$ & $35 \cdot 5(31)$ & $21 \cdot 4(28)$ \\
Predator Exclosure & $50 \cdot 0(42)$ & $39 \cdot 6(48)$ & $32 \cdot 0(19)$ \\
Food Addition & $49 \cdot 4(79)$ & $36 \cdot 0(100)$ & $26 \cdot 7(45)$ \\
Predator Exclosure + Food & $76 \cdot 3(59)$ & $58 \cdot 9(90)$ & $30 \cdot 1(93)$ \\
Weighted mean & $59 \cdot 9(207)$ & $42 \cdot 3(300)$ & $27 \cdot 4(197)$ \\
\hline
\end{tabular}

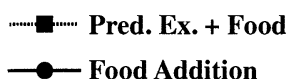

- - $\square$ - Pred. Exclosure

..... Controls

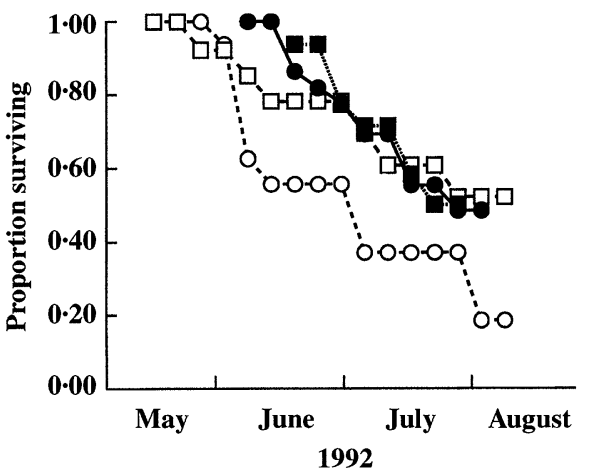

Fig. 3. Kaplan-Meier survival estimates of radiocollared adult female Arctic ground squirrels in 1992 on all trapping grids.

also no significant differences in survival among the grids when females that disappeared were assumed dead. This assumption was plausible because the movements of adult females were generally confined to small areas $(1.8 \mathrm{ha} \pm 1.3$ on the Control grids, personal observation) and because adult females, unlike adult males, rarely emigrate (Green 1977; McLean

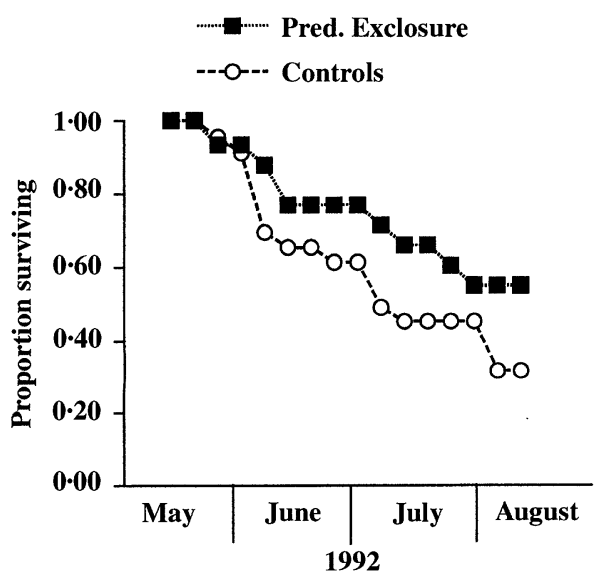

Fig. 4. Kaplan-Meier survival estimates of radiocollared adult male and female Arctic ground squirrels in 1992 on the Control grids and on the Predator Exclosure grid (Predator and Mammalian grids pooled)
1981). Thus, estimates of survival based on radiotelemetry reinforce those from trapping: ground squirrels on all treatments experienced similar, low survival during the summer of 1992 .

Approximately $20-50 \%$ of the squirrels died during the radiotracking period in 1992 and predation accounted for $93 \%$ (42 of 45 ) of these deaths. The proximate cause(s) of the remaining deaths was unknown. The proportion of radiocollared squirrels killed by predators ranged from 32 to $49 \%$ and did not differ significantly among grids for males $(G=0 \cdot 01$, d.f. $=1, P=0.92)$ or females $(G=5 \cdot 04$, d.f. $=3$, $P=0 \cdot 17$ ) (Table 3). Losses to avian and mammalian predators were similar on both the Control and Food Addition grids (Table 3). Avian predators accounted for all losses within the electric fences, indicating that these fences were effective at excluding large mammalian predators. However, since there were no differences in survival between this grid and the unfenced grids, avian predators on the fenced grids must have compensated for the squirrels taken by mammals on the unfenced grids.

It was not possible to distinguish between the relative impact of avian and mammalian predators on survival by comparing losses on the Predator Exclosure (both large mammals and raptors excluded) with that on the Mammalian Predator Exclosure (only large mammals excluded) because of low numbers of squirrels $(n=6)$ on the Mammalian Predator Exclosure.

\section{Overwintering survival (August-April)}

Major changes in numbers occurred overwinter (Fig. 2), especially from summer 1991 to spring 1992 and these were reflected in survival changes. Calculation of overwintering survival was complicated because different segments of the population enter hibernation at different times. In our study area, adult females tend to enter hibernation first (late JulyAugust), followed by adult males (August), followed by juveniles (late August-September) (T. Karels, personal communication). To estimate overwinter survival we carried out two analyses, one focusing on adults and the other primarily on juveniles. First, we Ecological Society Journal of Anima Ecology, 66, 527-541 
534

Effects of food and predation on squirrels

Table 3. Percentage of radiocollared squirrels killed by avian and mammalian predators in 1992. Numbers radiocollared in parentheses

\begin{tabular}{|c|c|c|c|c|c|}
\hline \multirow[b]{3}{*}{ Grid } & \multirow{2}{*}{\multicolumn{3}{|c|}{ Percentage of squirrels killed }} & \multicolumn{2}{|c|}{$\%$ Killed by } \\
\hline & & & & \multirow{2}{*}{$\begin{array}{l}\text { Avian } \\
\text { predators }\end{array}$} & \multirow{2}{*}{$\begin{array}{l}\text { Mammalian } \\
\text { predators }\end{array}$} \\
\hline & Males & Females & Total & & \\
\hline Controls & $23(13)$ & $65(20)$ & $49(33)$ & 45 & 55 \\
\hline Predator Exclosure* & $25(8)$ & $38(16)$ & $33(24)$ & 100 & 0 \\
\hline Food Addition & - & $44(25)$ & $44(25)$ & 64 & 36 \\
\hline Predator Exclosure + Food & - & $32(24)$ & $32(24)$ & 100 & 0 \\
\hline Totals & $24(21)$ & $45(85)$ & $41(106)$ & 63 & 24 \\
\hline
\end{tabular}

* Predator Exclosure includes both trapping grids within the fence.

determined whether adults known to be alive in the last week of June or in July were recaptured the next spring. This may underestimate male survival, but not female survival (see above). In this analysis we did not examine for the effect of weight differences among animals because squirrels were at the start of their growth phase leading to hibernation and thus their weights at this time were not indicative of their weights just prior to hibernation. Secondly, we determined whether squirrels (mainly juveniles plus some late hibernating adults, mainly males) caught during August were recaptured the next spring. Adults were included in this analysis because there may have been some immigration by animals onto the grids and rapid growth in juvenile males meant that they overlapped the weight of adult males still present. This may also underestimate survival because some squirrels may have dispersed from the grids following the last trapping session in the late summer. For both methods we used logistic regression analysis to partition out the factors that might affect survival.

For the first estimate based on adults $(n=228)$, the model which included the main effects (year $\chi^{2}=10.28$, d.f. $1, P<0.001$; sex $\chi^{2}=16.70$, d.f. 1 , $P<0.0001$; grid $\chi^{2}=8.68$, d.f. $3, P=0.034$ ) had the greatest explanatory power and the residual deviance was not significant $\left(\chi^{2}=13.08\right.$, d.f. $\left.10, P=0.219\right)$. None of the interaction effects were significant (sex: year: grid, $\chi^{2}=1 \cdot 78$, d.f. $3, P=0.629$; sex: grid, $\chi^{2}=2 \cdot 72$, d.f. $3, P=0.437$; year: grid, $\chi^{2}=5.98$, d.f. $3, P=0 \cdot 113$; year: sex, $\chi^{2}=2 \cdot 60$, d.f. $1, P=0 \cdot 107$ ). Adult female survival was $23 \%$ higher than adult male survival $(40 \cdot 1 \%, n=157$ vs. $16 \cdot 9 \%, n=71$, respectively). Over winter survival in 1990-91 was $19 \%$ higher than in $1991-92(44 \cdot 1 \%, n=93$ vs. $25 \cdot 2 \%$, $n=135$, respectively). Survival on the treatments ranked as follows: Controls $(47 \cdot 8 \%)>$ Predator Exclosure + Food $(35.4 \%)>$ Predator Exclosure $(27 \cdot 3 \%)>$ Food Addition (26.7\%). In females, survival was higher in 1990-91 (50\%) than 1991-92 $(34 \%)$, decreasing on all grids, except on the Control grid (Table 4). From the winter of 1990-91 to the winter of 1991-92, female survival decreased most on the Food Addition grid (by 38\%) followed by the
Predator Exclosure + Food (8\%), and the Predator Exclosure (4\%). In males, survival was higher in 1990 $91(32 \%)$ than $1991-92(5 \%)$, decreasing on all grids (Table 4).

For the second estimate based primarily on juveniles $(n=246)$ (late in the summer, there was some weight overlap between adults and juveniles, we assessed the importance of prehibernation weight and age (juvenile vs. adult). Neither of these contributed significantly to the model (weight, $\chi^{2}=0.002$, d.f. 1 ; age, $\chi^{2}=0.02$, d.f. 1 , both $P>0.9$ ), and were not included in the model. The final model included two of the main effects ( $\operatorname{sex} \chi^{2}=29.07$, d.f. $1, P<0.0001$, and grid $\chi^{2}=15.96$, d.f. $3, P=0.001$, but not year $\chi^{2}=2 \cdot 41$, d.f. $\left.1, P=0 \cdot 121\right)$ and the residual deviance was not significant $\left(\chi^{2}=10 \cdot 77\right.$, d.f. $\left.11, P=0 \cdot 463\right)$. None of the interaction effects were significant (sex: year: grid, $\chi^{2}=1.82$, d.f. $3, P=0.611$; year: grid, $\chi^{2}=1 \cdot 85$, d.f. $3, P=0.604$; year: sex, $\chi^{2}=0.51$, d.f. $1, P=0 \cdot 475$; sex: grid, $\chi^{2}=4 \cdot 18$, d.f. $3, P=0 \cdot 243$ ). Juvenile female survival was $33 \%$ higher than juvenile male survival $(61 \cdot 1 \%, n=131$ vs. $27 \cdot 8 \%, n=115$, respectively). Survival on the treatments ranked as follows: Controls $(63.6 \%)>$ Predator Exclosure $(51 \cdot 3 \%)>$ Predator Exclosure + Food $(43.5 \%)>$ Food Addition (29.8)\%). Though the year effect was not significant, as in the above estimate on adults, overall survival was higher over the winter of 1990 $91(53 \cdot 8 \%, n=104)$ than over the winter of $1991-$ $92(39 \cdot 4 \%, n=142)$, though males on Controls and females on the Predator Exclosure showed the opposite, with better survival over 1991-92 than over 1990-91. In females, survival was higher in 1990-91 $(70 \%)$ than $1991-92(53 \%)$, decreasing on all grids, except on the Predator Exclosure grid (Table 4) and it was lowest on the Food Addition grid. In males, overwinter survival was only slightly higher in 1990$91(29 \%)$ than in 1991-92 (27\%) (Table 4).

Thus, in general overwintering survival was higher in 1990-91 than in 1991-92, was always higher for females than males, was highest on the Control areas and lower on the fed grids. Thus, contrary to prediction, food addition did not improve overwinter survival, independent of whether predators were
Journal of

Ecology, 66, 527-54 
535

A.H. Hubbs \&

R. Boonstra

Table 4. Overwinter survival of male and female Arctic ground squirrels over two winters. Samples sizes in parentheses. Estimation methods described in text

\begin{tabular}{|c|c|c|c|c|c|}
\hline \multirow[b]{2}{*}{ Sex } & \multirow[b]{2}{*}{ Year } & \multicolumn{4}{|c|}{ Overwinter survival (\%) } \\
\hline & & Controls & $\begin{array}{l}\text { Predator } \\
\text { Exclosure }\end{array}$ & $\begin{array}{l}\text { Food } \\
\text { Addition }\end{array}$ & $\begin{array}{l}\text { Predator } \\
\text { Exclosure } \\
+ \text { Food }\end{array}$ \\
\hline \multicolumn{6}{|c|}{ Overwintering survival of adults captured in early summer } \\
\hline \multirow[t]{2}{*}{ Male } & $1990-91$ & $50 \cdot 0(10)$ & $33 \cdot 3(3)$ & $20 \cdot 0(10)$ & $25 \cdot 0(8)$ \\
\hline & 1991-92 & $16 \cdot 7(6)$ & $0(13)$ & $0(12)$ & $11 \cdot 0(9)$ \\
\hline \multirow[t]{2}{*}{ Female } & 1990-91 & $45 \cdot 4(11)$ & $41 \cdot 7(12)$ & $55 \cdot 5(27)$ & $50 \cdot 0(12)$ \\
\hline & 1991-92 & $57 \cdot 9$ (19) & $37 \cdot 5(16)$ & $17 \cdot 1(41)$ & $42 \cdot 1$ (19) \\
\hline \multicolumn{6}{|c|}{$\begin{array}{l}\text { Overwintering survival of juveniles (plus some late emerging adults) captured in } \\
\text { late summer }\end{array}$} \\
\hline \multirow[t]{2}{*}{ Male } & $1990-91$ & $50 \cdot 0(8)$ & $20 \cdot 0(10)$ & $18 \cdot 2(11)$ & $33 \cdot 3(12)$ \\
\hline & 1991-92 & $58 \cdot 8(17)$ & $25 \cdot 0(8)$ & $16 \cdot 7(21)$ & $17 \cdot 8(28)$ \\
\hline \multirow[t]{2}{*}{ Female } & $1990-91$ & $84 \cdot 6(13)$ & $71 \cdot 4(14)$ & $53 \cdot 8(13)$ & $69 \cdot 6(23)$ \\
\hline & $1991-92$ & $58 \cdot 8(17)$ & $85 \cdot 7(7)$ & $36.4(22)$ & $54 \cdot 5(22)$ \\
\hline
\end{tabular}

excluded. As expected, exclusion of predators did not improve overwinter survival.

\section{REPRODUCTION}

The percentage of females lactating differed among treatments and years (Table 5). There were significant differences between years $\left(\chi^{2}=6 \cdot 19, \quad\right.$ d.f. $=1$, $P=0.01)$, with mean levels being lower in 1991 $(61.6 \%)$ than in $1992(79 \cdot 8 \%)$. Treatments were not significantly different $\left(\chi^{2}=4 \cdot 81\right.$, d.f. $\left.=3, P=0 \cdot 19\right)$ but because of a possible interaction effect between years and treatments $\left(\chi^{2}=6.58\right.$, d.f. $\left.=3, P=0.09\right)$ and because some females were alive in both years (and thus the years were not independent), we analysed each year separately. There was no difference among grids in the percentage of females lactating in $1991\left(\chi^{2}=4 \cdot 81\right.$, d.f. $\left.=3, P=0 \cdot 19\right)$, but there was in $1992\left(\chi^{2}=11 \cdot 00\right.$, d.f. $\left.=3, P<0 \cdot 01\right)$, with $24-43 \%$ more lactating females occurring on the food addition grids.

We calculated mean litter sizes for each grid by dividing the number of young trapped within one month of emergence from their natal burrows (just prior to juvenile dispersal: McLean 1981; Lacey 1991) by the number of lactating females. This index therefore is the litter size recruited to the traps and includes a survival component between birth and emergence from the burrow. Since young could not be assigned to individual females following emergence, actual litter sizes (and hence neither standard errors nor a statistical test could be calculated) per female could not be calculated. Litter sizes were larger on the experimental grids than on the Controls, with the largest litters in both 1991 and 1992 occurring on the Predator Exclosure grid and on the Food Addition grid (Table 5). Litter sizes on the Predator Exclosure + Food grid were similar to those on the Controls in 1991, but were larger than those on the Controls in 1992. In 1991, we suspect the estimate on the Predator Exclosure + Food grid was underestimated because traps became saturated as we had too few available to us. Litter sizes obtained from embryo counts from a sample of pregnant squirrels killed on the Alaska Highway (road kills) averaged $4 \cdot 9( \pm 0 \cdot 5, n=11)$, indicating that trap-derived estimates were much lower. Thus,
(C) 1997 British Ecological Society Journal of Animal Ecology, 66, 527-541
Table 5. Effect of the experimental treatments on reproductive and emergence patterns in the Arctic ground squirrel. Sample sizes in parentheses

\begin{tabular}{|c|c|c|c|c|c|}
\hline & Year & Controls & $\begin{array}{l}\text { Predator } \\
\text { Exclosure }\end{array}$ & $\begin{array}{l}\text { Food } \\
\text { Addition }\end{array}$ & $\begin{array}{l}\text { Predator } \\
\text { Exclosure } \\
+ \text { Food }\end{array}$ \\
\hline Percentage of females lactating & $\begin{array}{l}1991 \\
1992\end{array}$ & $\begin{array}{l}62 \cdot 1(29) \\
53 \cdot 3(15)\end{array}$ & $\begin{array}{l}46 \cdot 9(32) \\
61 \cdot 5(13)\end{array}$ & $\begin{array}{l}61 \cdot 9(63) \\
96 \cdot 3(27)\end{array}$ & $\begin{array}{l}72 \cdot 5(40) \\
85 \cdot 3(34)\end{array}$ \\
\hline Litter size* & $\begin{array}{l}1991 \\
1992\end{array}$ & $\begin{array}{l}1 \cdot 4(18) \\
0.9(11)\end{array}$ & $\begin{array}{l}3 \cdot 0(14) \\
2 \cdot 5(8)\end{array}$ & $\begin{array}{l}3.0(39) \\
1.5(27)\end{array}$ & $\begin{array}{l}1 \cdot 6(30) \\
1.4(29)\end{array}$ \\
\hline $\begin{array}{l}\text { Emergence } \\
\text { Date of juveniles }\end{array}$ & $\begin{array}{l}1991 \\
1992\end{array}$ & $\begin{array}{l}\text { 21-24 June } \\
4-16 \text { July }\end{array}$ & $\begin{array}{l}23 \text { June } \\
6 \text { July }\end{array}$ & $\begin{array}{l}17 \text { June } \\
26 \text { June }\end{array}$ & $\begin{array}{l}13 \text { June } \\
27 \text { June }\end{array}$ \\
\hline
\end{tabular}

* Number of lactating females in parentheses. 
536

Effects of food and

predation on

squirrels
(C) 1997 British

Ecological Society

Journal of Animal

Ecology, 66, 527-541 either (i) we underestimated actual litter size on all grids, or (ii) mortality prior to emergence from the natal burrow was high. Litter sizes on all grids, but particularly the Food Addition grid and the Controls, declined from 1991 to 1992.

Although the exact emergence dates of juveniles on the different grids were unknown, we used the dates of first capture in traps as an index of date of emergence (which was corroborated by sightings of juveniles above ground). The dates of first capture also agreed with the typical dates of emergence (mid-June to early July) reported from previous studies of Arctic ground squirrels in the south-western Yukon (Green 1977; McLean 1981; Lacey 1991). In our study there were grid and year effects on emergence dates. Juveniles emerged at least 4-28 days earlier on the food grids than on the other grids (Table 5). Emergence occurred 1-4 weeks later in 1992 than 1991 on all the grids Since oestrus occurs within 3-4 days of emergence and both gestation and the length of time the young spend in the burrow are very constant ( 25 days and 27 days, respectively, Lacey 1991), earlier appearance of the young on the food grids must mean earlier emergence of their mothers in spring.

Thus, food had major effects on reproduction and these effects became even more pronounced following the overwinter decline from 1991 to 1992 . The difference in the percentage of females that bred on the food grids over those breeding on the non-food grids was much greater in 1992 than 1991. In addition, young emerged later in 1992 than 1991, and young emerged considerably earlier on food grids than on non-food grids. The difference between food and nonfood grids, however, was not reflected in the litter size differences which may simply indicate that those females on the non-fed grids that were able to breed did well.

\section{IMMIGRATION}

The differences in density among areas could possibly be explained by immigration rather than by differences in survival or reproduction. We defined animals to be immigrants only if they were newly tagged adults (those not caught as juveniles) which had been caught on the trapping grid at least twice from spring to late summer and calculated the proportion occurring in 1991 and $1992 ; 1990$ was excluded as this was the first year the grids were trapped and trapping effort was lower. For females, this index probably overestimates immigration rates because of capture of squirrels living on the edge of the trapping grid but within their home range (Karels, personal communication). For males, the index is probably a reasonable reflection of true immigration given their propensity to move during and after the breeding season (McLean 1981; Lacey 1991). We examined whether year, sex, and treatment affected immigration rates. Because of significant interaction effects between year and sex and between year and treatment, we determined first whether there was a year effect and then examined for differences within years. The mean immigration rate in $1991(33.7 \%)$ was significantly higher than that in $1992(24.6 \%)\left(\chi^{2}=4.78\right.$, d.f. $\left.=1, P=0.03\right)$ (Table $6)$. In 1991, treatments had mean immigration rates varying between 23 and $39 \%$ and there was no difference among treatments $\left(\chi^{2}=2 \cdot 36\right.$, d.f. $\left.=3, P=0.50\right)$ or between sexes $\left(\chi^{2}=0.47\right.$, d.f. $\left.=1, P<0.49\right)$, and no interaction effect $\left(\chi^{2}=2 \cdot 83\right.$, d.f. $\left.=3, P<0.42\right)$. In 1992 , treatments had mean immigration rates varying between 8 and 35 , and there were marginal differences among treatments $\left(\chi^{2}=7 \cdot 34\right.$, d.f. $\left.=3, P=0.06\right)$, significant differences between sexes $\left(\chi^{2}=6 \cdot 27\right.$, d.f. $=1$, $P=0.01)$, and no interaction effect $\left(\chi^{2}=5.54\right.$, d.f. $=3, P<0 \cdot 14)$. In 1991, males had similar immigration rates $(30 \cdot 3 \%)$ to 1992 values $(31 \cdot 8 \%)$, but females had markedly higher ones $(35 \cdot 3 \%$ vs. $20 \cdot 7 \%$, respectively). Thus, the population decline from 1991 to 1992 was reflected in lower female, but not male movement. There was no consistent effect of food addition on females: in 1991, immigration rates were comparable on all treatments; in 1992, the food addition grids (both treatments) had immigration rates between 2 and 8 times that on the non-fed grids.

\section{GROWTH AND WEIGHT DYNAMICS}

We calculated the absolute growth rates of juvenile squirrels from emergence until mid-August for 1991 and 1992. We performed a simple linear regression and an exponential regression, with week and weight as the independent and dependent variables, respectively, for each squirrel weighed $\geqslant 5$ times. Since linear models fit the data slightly better than exponential models (linear: $r^{2}=0 \cdot 83$; exponential: $r^{2}=0 \cdot 81$ ), we linearly extrapolated growth rates covering only part of the time period to that of the whole period. Only squirrels weighed more than a week apart were included in the following analyses and to ensure independence, each squirrel only contributed one growth rate to an analysis.

Since juvenile males grew significantly faster than females $\left(7 \cdot 1 \mathrm{~g} \mathrm{day}^{-1}\right.$ vs. $5 \cdot 7 \mathrm{~g} \mathrm{day}^{-1}$, respectively; oneway ANOVA: $\left.F_{1,123}=7 \cdot 95, P=0 \cdot 006\right)$, we analysed growth rates separately for each sex. The growth rates of males differed significantly among the grids (with that on only the Predator Exclosure being lower than that on the food additions grids) with the grids ranked as follows: Predator Exclosure + Food $>$ Food Addition $>$ Controls $>$ Predator Exclosure (Table 7). Males on the food addition grids were growing $2 \cdot 0-2 \cdot 5 \mathrm{~g}$ more per day than the nonfed grids. The growth rates of females did not differ significantly among the grids, though they show a ranking similar to that of males: Predator Exclosure + Food $>$ Food Addition $>$ Predator Exclosure $>$ Controls. Females on the food addition grids were growing $0 \cdot 7-1.8 \mathrm{~g}$ 
537

A.H. Hubbs \&

R. Boonstra
(C) 1997 British

Ecological Society Journal of Animal Ecology, 66, 527-541

Table 6. Proportion of immigrants on the experimental areas. Immigrants were defined to be newly tagged adult squirrels (those not caught at as juveniles) which had been caught on the trapping grid at least two times. Sample sizes in parentheses

\begin{tabular}{llllll}
\hline Year & Sex & Controls & $\begin{array}{l}\text { Predator } \\
\text { Exclosure }\end{array}$ & $\begin{array}{l}\text { Food } \\
\text { Addition }\end{array}$ & $\begin{array}{l}\text { Predator } \\
\text { Exclosure } \\
+ \text { Food }\end{array}$ \\
\hline 1991 & Males & $0.26(23)$ & $0.27(22)$ & $0.29(24)$ & $0.37(35)$ \\
& Females & $0.46(41)$ & $0.21(34)$ & $0.37(73)$ & $0.34(56)$ \\
& Mean & $0.39(64)$ & $0 \cdot 23(56)$ & $0.35(97)$ & $0.35(86)$ \\
1992 & Males & $0.12(16)$ & $0.80(5)$ & $0.33(9)$ & $0.33(36)$ \\
& Females & $0.04(23)$ & $0.12(17)$ & $0.35(34)$ & $0.21(47)$ \\
& Mean & $0.08(39)$ & $0.27(22)$ & $0.35(43)$ & $0.26(83)$ \\
\hline
\end{tabular}

more per day than the nonfed grids. Growth rates did not differ significantly among years for either sex.

To compare among treatments and years, we examined adult weights following emergence from hibernation in spring. Since males weighed $15 \%$ more than females in spring (one-way ANOVA: $F_{1,338}=44 \cdot 55$, $P=0 \cdot 0001$ ), we examined for differences among grids and years separately for each sex. Males weighed significantly more in 1990 than 1992 and significantly more on fed grids than on nonfed grids (Table 8). Females showed the same general relationship, weighing more in 1990 and 1991 than in 1992 and more on the fed grids than on nonfed grids which differed significantly from each other (Predator Exclosure $>$ Controls). However, the relationship in females was complicated by a significant interaction effect between grids and years, largely because females on the Predator Exclosure in 1990 (but not in 1991 and 1992) had weights similar to the females on the fed grids in that year. To assess the importance of this interaction, we divided the mean square of the main effects by that of the interaction mean square (as recommended by Gilbert 1989), and both main effects remained significant. One of the reasons for the interaction effect was the much lower spring weights in females on the Food grid in 1992 than in 1991 (99g lower) whereas weights in 1990 and 1991 and on the Predator Exclosure + Food in all three springs showed little change. A similar trend occurred in 1992 males on the Food grid (97g lower in 1992 than 1991). Thus, juveniles generally grew faster and adults emerged from hibernation at heavier weights on the food grids than on

Table 7. Growth rates of juvenile Arctic ground squirrels. Sample sizes in parentheses. Identical superscript indicates means that were not significantly different

\begin{tabular}{|c|c|c|c|c|c|}
\hline \multirow[b]{2}{*}{ Sex } & \multirow[b]{2}{*}{ Year } & \multicolumn{4}{|c|}{ Daily growth rate $\left(\mathrm{g} \mathrm{day}^{-1}\right)$} \\
\hline & & Controls & $\begin{array}{l}\text { Predator } \\
\text { Exclosure }\end{array}$ & $\begin{array}{l}\text { Food } \\
\text { Addition }\end{array}$ & $\begin{array}{l}\text { Predator } \\
\text { Exclosure } \\
+ \text { Food }\end{array}$ \\
\hline \multirow[t]{3}{*}{ Male } & 1991 & $6 \cdot 4 \pm 0 \cdot 3(11)$ & $5 \cdot 7 \pm 0 \cdot 6(7)$ & $7 \cdot 7 \pm 0 \cdot 6(18)$ & $8.8 \pm 0.6(9)$ \\
\hline & 1992 & $5 \cdot 8 \pm 0.3(2)$ & $4 \cdot 6 \pm 0.5(2)$ & $6 \cdot 3 \pm 2 \cdot 7(2)$ & $7 \cdot 2 \pm 0.8(9)$ \\
\hline & Mean & $6 \cdot 3 \pm 0.3(13)^{a, b}$ & $5.4 \pm 0.5(9)^{a}$ & $7 \cdot 5 \pm 0.6(20)^{b}$ & $8 \cdot 0 \pm 0 \cdot 5(18)^{b}$ \\
\hline \multirow[t]{3}{*}{ Female } & 1991 & $5.9 \pm 0.8(6)$ & $4 \cdot 3 \pm 0 \cdot 5(4)$ & $5 \cdot 6 \pm 0 \cdot 6(19)$ & $6 \cdot 6 \pm 0.7(10)$ \\
\hline & 1992 & $2 \cdot 1 \pm 2 \cdot 1(3)$ & $5.9 \pm 0.6(5)$ & $6 \cdot 3 \pm 1 \cdot 2(13)$ & $5.9 \pm 1 \cdot 6(5)$ \\
\hline & Mean & $4 \cdot 6 \pm 1 \cdot 0(9)^{\mathrm{a}}$ & $5 \cdot 2 \pm 0 \cdot 5(9)^{\mathrm{a}}$ & $5 \cdot 9 \pm 0.6(32)^{a}$ & $6 \cdot 4 \pm 0 \cdot 7(15)^{\mathrm{a}}$ \\
\hline
\end{tabular}

Statistical analysis: two-way ANCovA

\begin{tabular}{|c|c|c|c|c|c|c|}
\hline & \multicolumn{3}{|c|}{ Male } & \multicolumn{3}{|c|}{ Female } \\
\hline & $F$ & d.f. & $P$ & $F$ & d.f. & $P$ \\
\hline $\begin{array}{c}\text { Covariate } \\
\text { weight }\end{array}$ & \multicolumn{3}{|c|}{ Covariate } & $7 \cdot 0$ & 1 & 0.01 \\
\hline \multicolumn{7}{|l|}{ Main effects } \\
\hline Grid & $5 \cdot 2$ & 3 & $0 \cdot 004$ & $1 \cdot 6$ & 3 & \\
\hline Year & $0 \cdot 6$ & 1 & & 0.00 & 1 & \\
\hline \multicolumn{7}{|l|}{ Interactions } \\
\hline$G \times \mathrm{Y}$ & $0 \cdot 1$ & 3 & & $2 \cdot 0$ & 3 & \\
\hline
\end{tabular}


538

Effects of food and predation on squirrels

Table 8. Spring weights of adult Arctic ground squirrels. Samples sizes in parentheses. Identical superscript letters among years and among grids indicate means that were not significantly different

\begin{tabular}{|c|c|c|c|c|c|c|c|c|}
\hline Sex & Year & & Controls & & $\begin{array}{l}\text { Predator } \\
\text { Exclosure }\end{array}$ & $\begin{array}{l}\text { For } \\
\text { Ad }\end{array}$ & & $\begin{array}{l}\text { Predator } \\
\text { Exclosure } \\
+ \text { Food }\end{array}$ \\
\hline \multirow[t]{4}{*}{ Male } & \multicolumn{2}{|l|}{$1990^{\mathrm{a}}$} & \multicolumn{2}{|c|}{$563 \pm 22(8)$} & $518 \pm 13(2)$ & \multicolumn{2}{|c|}{$632 \pm 45(5)$} & $770 \pm 0(1)$ \\
\hline & \multicolumn{2}{|l|}{$1991^{\mathrm{a}, \mathrm{b}}$} & \multicolumn{2}{|c|}{$528 \pm 35(12)$} & $450 \pm 20(10)$ & \multicolumn{2}{|c|}{$594 \pm 14(6)$} & $629 \pm 21(8)$ \\
\hline & \multicolumn{2}{|l|}{$1992^{\mathrm{b}}$} & \multicolumn{2}{|c|}{$388 \pm 43(7)$} & $585 \pm 0(1)$ & \multicolumn{2}{|c|}{$497 \pm 57(5)$} & $570 \pm 33(11)$ \\
\hline & \multicolumn{2}{|l|}{ Mean } & \multicolumn{2}{|c|}{$502 \pm 24(27)^{\mathrm{a}, \mathrm{b}}$} & $471 \pm 19(13)^{\mathrm{a}}$ & \multicolumn{2}{|c|}{$576 \pm 26(16)^{b, c}$} & $604 \pm 22(20)^{\mathrm{c}}$ \\
\hline \multirow[t]{4}{*}{ Female } & \multicolumn{2}{|l|}{$1990^{\mathrm{a}}$} & \multicolumn{2}{|c|}{$430 \pm 7(9)$} & $480 \pm 19(12)$ & \multicolumn{2}{|c|}{$497 \pm 14(26)$} & $507 \pm 43(5)$ \\
\hline & \multicolumn{2}{|l|}{$1991^{\mathrm{a}}$} & \multicolumn{2}{|c|}{$367 \pm 12(27)$} & $448 \pm 8(28)$ & \multicolumn{2}{|c|}{$514 \pm 11(48)$} & $507 \pm 10(27)$ \\
\hline & \multicolumn{2}{|l|}{$1992^{\mathrm{b}}$} & \multicolumn{2}{|c|}{$337 \pm 14(12)$} & $365 \pm 15(11)$ & \multicolumn{2}{|c|}{$415 \pm 17(28)$} & $482 \pm 14(32)$ \\
\hline & \multicolumn{2}{|l|}{ Mean } & \multicolumn{2}{|c|}{$372 \pm 9(48)^{a}$} & $438 \pm 9(51)^{\mathrm{b}}$ & \multicolumn{2}{|c|}{$482 \pm 9(102)^{c}$} & $500 \pm 10(64)^{\mathrm{c}}$ \\
\hline \multicolumn{9}{|c|}{ Statistical analysis: two-way ANOVA } \\
\hline & & \multicolumn{3}{|c|}{ Male } & Female & & & \\
\hline & & $F$ & d.f. & $P$ & $F$ & d.f. & $P$ & \\
\hline Main eff & cts & & & & & & & \\
\hline Grid & & $6 \cdot 8$ & 3 & 0.0005 & $26 \cdot 0$ & 3 & 0.0001 & \\
\hline Year & & $3 \cdot 5$ & 2 & $0 \cdot 04$ & $22 \cdot 2$ & 2 & $0 \cdot 0001$ & \\
\hline Interacti & & & & & & & & \\
\hline$G \times \mathrm{Y}$ & & $1 \cdot 3$ & 6 & $0 \cdot 29$ & $3 \cdot 1$ & 6 & 0.007 & \\
\hline
\end{tabular}

the other grids. In general, all animals weighed significantly less at emergence in 1992 than in other years.

\section{Discussion}

Our results indicate that food and predation had major impacts on ground squirrels in the boreal forest, but they were complicated by two major factors. First, our experiments occurred over a time period (199092) when the densities of the major prey species in our valley (the snowshoe hare) declined by $80 \%$ (Krebs et al. 1995), while at the same time the densities of the major predators remained relatively constant (Boutin et al. 1995). Secondly, severe weather conditions in the late winter and spring of 1992 served to converge treatment effects. Exclusion of predators had virtually no effect on any demographic variable measured, except for population densities in 1991 when they were approximately double those of the Controls (Fig. 1) and, unexpectedly, litter sizes which were almost double those on the Controls (Table 5). Addition of food increased densities 3-8 times, generally increased reproductive traits (increased proportion of females lactating by about $30 \%$ [but only in 1992], doubled litter sizes, resulted in earlier emergence of juveniles), increased immigration rates (but only 1992), had no effect on active season or overwinter survival rates (Tables 2 and 4), resulted in heavier females though not males at emergence in spring (Table 8), and resulted in more rapid growth rates in juvenile males but not in juvenile females (Table 7). Both the exclusion of predators and the addition of food produced effects that were very similar to those seen with the addition of food alone: only in 1992 were densities on the Predator Exclosure + Food grid two times that on the Food Addition grid (Fig. 2) and these we believe were the result of difficulties of distributing feed on the Food Addition grid during the spring of 1992 (see below). Thus, our results are consistent with the hypothesis that food, not predation, was the dominant factor acting on ground squirrel populations during the peak and early decline of the hare populations: food addition clearly has major positive effects on density, reproduction, and aspects of growth, but exclusion of predators had almost no effect in enhancing any demographic parameter.

However, this conclusion is clearly at odds with the marked decline in active season survival data from 1990 to 1992 (Table 2) on all grids, irrespective of treatment. This decline was coincident with the decline in the hare population but constant high predator population indicating that predator pressure increased significantly on ground squirrels in 1992 (M. O'Donoghue, personal communication; F. Doyle, personal communication). At this time predators also shifted to alternative food sources such as red squirrels (Stuart-Smith \& Boutin 1995). One major reason that our predator exclosures may have had no effect is that we were unable to completely remove the avian component, though we were successful at removing the mammalian component. All squirrels killed on the

predator exclosures in 1992 were killed by raptors Journal of Animal Ecology, 66, 527-541 
539

A.H. Hubbs \&

R. Boonstra

(C) 1997 British

Ecological Society

Journal of Animal

Ecology, 66, 527-541
(Table 3). On the Predator Exclosure, the monofilament nylon, which was intended to act as a barrier against avian predators, did not completely prevent great horned owls and goshawks from killing prey under it, presumably because of breaks in the nylon which occurred with increasing frequency every winter after it was set up (K. Stuart-Smith \& S. Boutin, personal communication). On the Predator Exclosure + Food, we had no such barrier and thus, avian predators had unrestricted access to the ground squirrels. Thus, we suggest that the avian predator component of the community is able to act in a compensatory fashion, replacing much of the predation normally accounted for by the mammalian predator component (Table 3). We suggest that had we been able to totally prevent predation within the predator exclosures, ground squirrels would have survived much better there and that then predation would have interacted with food in the manner predicted.

Since our large-scale experimental grids were not replicated, the results have to be interpreted with some caution. The differences among the grids could have been due primarily to site-specific differences instead of the experimental manipulations. We do not think this is likely for five reasons: (i) we did replicate the Controls and these grids were largely similar to each other over time and different from the experimental grids in most demographic parameters; (ii) the percentage cover of each main habitat types was similar among the grids (Table 1); (iii) differences in density among the grids remained despite standardization of the data to that on the Controls for habitat variation; (iv) demographic trends (e.g. large litter sizes, faster growth rates, and higher body weights) were similar on both food grids and for these parameters they should have been; and (v) the trends observed on the food grids are consistent with those of earlier food addition studies on vertebrates (see Boutin 1990 for review).

Our study is the first to assess the relative impact of food addition and predation concurrently on a mammal other than a microtine (Desy \& Batzli 1989) or lagomorph (Krebs et al. 1995). Earlier studies with sciurids have examined the separate roles either of food (Sullivan 1990; Dobson \& Kjelgaard 1985a,b; Klenner \& Krebs 1991) or of predation (Carl 1971; Green 1977), but not of both together. These studies suggested that food rather than predation limits ground squirrel populations. Our results indicate that both food and predators interact to limit Arctic ground squirrel populations in the boreal forest ecosystem. The effects of this interaction was most evident during the late decline phase of the hare cycle when predation upon squirrels was high.

The majority of the geographical range of the Arctic ground squirrel lies in the alpine and tundra regions of North America (Banfield 1974). The adaptations that work well for squirrels in these zones, particularly those permitting them to see predators while the latter are still a long way off, may be hampered by forest vegetation, and thus these 'forest ground squirrels' may be at disadvantage relative to those in more open habitats. Though Carl (1971) and Green (1977) emphasized the role of social behaviour in regulating Arctic ground squirrel populations in tundra and alpine habitats, predation may play a more important in the boreal forest. Consistent with this argument is that of all the potential mammalian prey in the boreal forest that could buffer the predators from the decline in the snowshoe hare population (several species of small mammal, red squirrels, ground squirrels), only the Arctic ground squirrel fluctuated in response to the snowshoe hare cycle (though with a 2-year lag, Boutin et al. 1995; Stuart-Smith \& Boutin 1995; Boonstra et al. personal observation). Similar 2-year lags in declines have been observed in other ground squirrel species and these were also associated with hare declines (Adamcik et al. 1979; Keith \& Cary 1991). Though the red squirrel, which is restricted to the boreal forest in the Yukon, is also preyed upon during the hare decline, predation has little impact on their populations (Stuart-Smith \& Boutin 1995). Thus, red squirrels appear to be much better adapted to the range of predators found in the boreal forest than are the ground squirrels. Spruce grouse populations in our area also declined simultaneously with the hares, but showed no lag (Boutin et al. 1995; K. Martin unpublished). The synchronizing effects of predators on hares, Arctic ground squirrels, and spruce grouse in the Yukon may thus be analogous with that on small mammals and grouse species in Fennoscandia (Hörnfeldt 1978; Angelstam, Lindstöm \& Widen 1984; Korpimäki \& Norrdahl 1989).

The density of squirrels declined markedly on all grids from summer 1991 to spring 1992 (Fig. 2). This appeared to be a result of poor overwinter survival rather than prey-shifting by predators during the summer of 1991 (Table 4). Though we are not unequivocally certain of the cause, the evidence is consistent with the hypothesis that weather, acting primarily through late heavy snowfalls and delayed snowmelt in spring 1992, directly reduced access to food and thus survival during the critical spring period. In our area, squirrels typically emerge from hibernation from mid-April (males) to the first week in May (females) (McLean 1981; T. Karels, personal communication). Normally, an average $25 \cdot 1 \mathrm{~cm}$ of snow falls during April and May (based on data from 1967 to 1994) and snow pack melts rapidly, being virtually gone by 10 May. In 1992, twice as much snow fell $(47.6 \mathrm{~cm})$ in April and May (the last falling on 19-20 May $7.7 \mathrm{~cm}$ ), and snow did not melt from most of the forest floor until the end of May. Food addition, which had major positive effects on demography in summer, should have ameliorated this loss: in the case of the Predator Exclosure + Food it seemed to; in the case of the Food Addition grid, it did not. During snowmelt (when soft snow made it impossible to use either snow- 
540

Effects of food and predation on

squirrels

(C) 1997 British Ecological Society Journal of Animal Ecology, 66, 527-541 machines and all terrain vehicles), we continued distributing food on Predator Exclosure + Food by hand from stockpiles set up in March. We could not do this on the Food Addition grid because both grizzly bears and moose roamed the entire area and devoured any concentrations of food. During a typical year, a rapid snowmelt meant that the Food grid was without excess chow for only a short time. However, in 1992 the Food grid received only $300 \mathrm{~kg}$ of chow in April and $200 \mathrm{~kg}$ to 27 May compared with 1125 and $850 \mathrm{~kg}$, respectively, on the Predator Exclosure + Food grid. The consequences for squirrels on the Food grid were as follows: they showed the largest density decline (Fig. 2), the lowest overwinter survival for adult and juvenile females (Table 4), a greater decline in spring body weights than on the Predator Exclosure + Food (Table 8), and the highest subsequent immigration by adults (Table 6) (as would be expected if it had much lower densities relative to its available food supply). The impact of detrimental weather during the critical spring period has also been reported by Phillips (1984), who found that a delayed snowmelt severely restricted reproduction in golden-mantled ground squirrel (S. saturatus Rhoads) and by Morton \& Sherman (1978) found that a month long spring snowstorm resulted in extremely poor survival, delayed breeding and reduced reproduction in Belding's ground squirrel ( $S$. beldingi).Thus, the poor spring conditions in 1992 serves to highlight the sensitivity of ground squirrels to their food resources, particularly at this time.

Since our intensive trapping for ground squirrels first began over 2 years after the experimental treatments were established in $1987-88$, the population regulatory changes the populations could have made over that time (i.e. improved rates of survival and/or reproduction) to adjust to the new conditions were not observed. Thus, by 1990 we were probably observing equilibrium effects on our populations (and hence we were observing population limitation) rather than transient, density-dependent effects of population regulation. To observe population regulatory effects, the factors (food addition and predator removal) that caused the experimental populations to reach new limits must be removed and the populations allowed to decay back to control levels. This work is currently being carried out.

\section{Acknowledgements}

We thank S. Boutin, D. Hik, W. Hochachka, R. Ims, T. Karels, C. Krebs, J. Millar, M. O’Donoghue, C. Rohner, A. Sinclair, J. Smith and N. Yoccoz for helpful criticism of the manuscript. We thank N. Yoccoz, R. A. Ims, C. Krebs, W. Hochachka and B. Anholt for statistical advice. We thank L. Aus, A. Byrom, T. Karels and S. Mallick for field assistance. This research was funded by a Collaborative Special Project grant and by an individual operating grant from the Natural Sciences and Engineering Research Council of Canada. This is contribution 63 of the Kluane Boreal Forest Ecosystem Project.

\section{References}

Abacus Concepts (1994) Survival Analysis Statistics for Statsview. Abacus Concepts Inc., Berkeley, CA.

Adamcik, R.S., Todd, A.W. \& Keith, L.B. (1979) Demographic and dietary responses of red-tailed hawks during a snowshoe hare fluctuation. Canadian Field-Naturalist, 93, 16-27.

Agresti, A. (1990) Categorical Data Analysis. John Wiley \& Sons, New York.

Angelstam, P., Lindstöm, E. \& Widen, P. (1984) Role of predation in short-term population fluctuations of some birds and mammals in Fennoscandia. Oecologia, 62, 199208.

Banfield, A.W.F. (1974) The Mammals of Canada. National Museum of Canada and University of Toronto Press, Toronto, Ontario.

Batzli, G.O. \& Sobaski, S.T. (1980) Distribution, abundance, and foraging patterns of ground squirrels near Atkasook, Alaska. Arctic and Alpine Research, 12, 501-510.

Blokpoel, H. \& Tessier, G.D. (1984) Overhead wires and monofilament lines exclude ring-billed gulls from public places. Wildlife Society Bulletin, 12, 55-58.

Boonstra, R. \& Craine, I.M.T. (1986) Natal nest location and small mammal tracking with a spool-and-line technique. Canadian Journal of Zoology, 64, 1034-1036.

Boutin, S. (1990) Food supplementation experiments with terrestrial vertebrates: patterns, problems, and the future. Canadian Journal of Zoology, 68, 203-220.

Boutin, S., C.J. Krebs, R. Boonstra et al. (1995) Population changes of the vertebrate community during a snowshoe hare cycle in Canada's boreal forest. Oikos, 74, 69-80.

Boutin, S., Krebs, C.J., Sinclair, A.R.E. \& Smith, J.N.M. (1986) Proximate causes of losses in a snowshoe hare population. Canadian Journal of Zoology, 64, 606-610.

Carl, E.A. (1971) Population control in arctic ground squirrels. Ecology, 52, 395-413.

Clutton-Brock, T.H., Albon, S.D. \& Guinness, F.E. (1987) Interactions between population density and maternal characteristics affecting fecundity and juvenile survival in red deer. Journal of Animal Ecology, 56, 857-871.

Collett, D. (1994) Modelling Survival Data in Medical Research. Chapman \&Hall, London.

Day, R.W. \& Quinn, G.P. (1989) Comparisons of treatment after an analysis of variance in ecology. Ecological Monographs, 59, 433-463.

Desy, E.A. \& Batzli, G.O. (1989) Experimental studies of vole populations: effects of food and predation on demography of prairie voles. Ecology, 70, 411-421.

Dobson, F.S. \& Kjelgaard, J.D. (1985a) The influence of food resources on life history in Columbian ground squirrels. Canadian Journal of Zoology, 63, 2105-2109.

Dobson, F.S. \& Kjelgaard, J.D. (1985b) The influence of food resources on population dynamics in Columbian ground squirrels. Canadian Journal of Zoology, 63, 20952104.

Erlien, D.A. \& Tester, J.R. (1984) Population ecology of sciurids in northwestern Minnesota. Canadian Field-Naturalist, 98, 1-6.

Ford, R.G. \& Pitelka, F.A. (1984) Resource limitation in populations of the California vole. Ecology, 65, 122-136.

Gagnon, J., Roth, J.M., Carroll, M., Hofmann, R., Haycock, K.A., Plamondon, J., Feldman Jr., D.S. \& Simpson, J. (1990) SuperANOVA - Accessible General Linear Modeling. Abacus Concepts, Inc., Berkely, California. 
541

A.H. Hubbs \&

R. Boonstra
Gilbert, N. (1989) Biometrical Interpretation: Making Sense of Statistics in Biology. Oxford Scientific Publications, Oxford.

Green, J.E. (1977) Population regulation and annual cycles in the Arctic ground squirrel. MSc thesis, University of British Columbia, Vancouver, B.C.

Hörnfeldt, B. (1978) Synchronous population fluctuations in voles, small game, owls, and tularemia in northern Sweden. Oecologia, 32, 145-164.

Keith, L.B. (1990) Dynamics of snowshoe hare populations. Current Mammalogy, 2, 119-195.

Keith, L.B. \& Cary, J.R. (1991) Mustelid, squirrel, and porcupine population trends during a snowshoe hare cycle. Journal of Mammalogy, 72, 373-378.

Klenner, W. \& Krebs, C.J. (1991) Red squirrel population dynamics. I. The effect of supplemental food on demography. Journal of Animal Ecology, 60, 961-978.

Korpimäki, E. \& Norrdahl, K. (1989) Predation of Tengmalm's owls: numerical, functional responses and dampening impact on population fluctuations of microtines. Oikos, 54, 154-164.

Krebs, C.J. \& Boonstra, R. (1984) Trappability estimates for mark-recapture data. Canadian Journal of Zoology, 62 2440-2444.

Krebs, C.J., Boonstra, R., Boutin, S.A., Dale, M.R.T., Hannon, S.J., Martin, K., Sinclair, A.R.E., Turkington, R. \& Smith, J.N.M. (1992) What drives the snowshoe hare cycle in Canada's Yukon? Wildlife 2001: Populations (eds D. McCullough \& R. Barrett), pp. 886-896. Elsevier, London.

Krebs, C.J., Boutin, S.A., Boonstra, R., Sinclair, A.R.E., Smith, J.N.M, Dale, M.R.T., Martin, K. \& Turkington, R. (1995) Impact of food and predation on the snowshoe hare cycle. Science, 269, 1112-1115.

Lacey, E.A. (1991) Reproductive and dispersal strategies of male Arctic ground squirrels (Spermophilus parryii plesius). $\mathrm{PhD}$ thesis, University of Michigan, Ann Arbor.

Marcström, V., Engren, E. \& Kenward, R.E. (1988) The impact of predation on boreal tetranoids during vole cycles: an experimental study. Journal of Animal Ecology, 57, 859-872.

Marcström, V. Keith, L.B., Engren, E. \& Cary, J.R. (1989) Demographic responses of Arctic hares (Lepus timidus) to experimental reductions of red foxes (Vulpes vulpes)and martens (Martes martes). Canadian Journal of Zoology, 67, 658-668.

McLean, I.G. (1981) Social ecology of the Arctic ground squirrel Spermophilus parryii. PhD thesis, University of Alberta, Edmonton, Alberta.

McNamara, J.M. \& Houston, A.I. (1987) Starvation and predation as factors limiting population size. Ecology, 68, 1515-1519.

Messier, F. \& Crête, M. (1985) Moose-wolf dynamics and the natural regulation of moose populations. Oecologia, 65, 503-512.

Mitchell, P., Arthur, W. \& Farrow, M. (1992) An investigation of population regulation using factorial models. Journal of Animal Ecology, 61, 591-598.

Morton, M.L. \& Sherman, P.W. (1978) Effects of a spring snowstorm on behavior, reproduction and survival of Belding's ground squirrels. Canadian Journal of Zoology, 56, 2578-2590

Murie, J.O. \& Boag, D.A. (1984) The relationship of body weight to overwinter survival in Columbian ground squirrels. Journal of Mammalogy, 65, 688-690.

O'Donoghue, M. \& Krebs, C.J. (1992) Effects of sup- plemental food on snowshoe hare reproduction and juvenile growth at a cyclic population peak. Journal of Animal Ecology, 61, 631-641.

Otis, D.L., Burnham, K.P., White, G.C. \& Anderson, D.R. (1978) Statistical inference for capture data from closed populations. Wildlife Monographs, 62, 1-135.

Phillips, J.A. (1984) Environmental influences on reproduction in the golden-mantled ground squirrel. The Biology of Ground-Dwelling Squirrels (eds J. O. Murie \& G. Michener), pp. 108-124. University of Nebraska Press, Lincoln, Nebraska.

Pollock, K.H., Winterstein, S.R., Bunck, C.M. \& Curtis, P.D. (1989) Survival analysis in telemetry studies: the staggered entry design. Journal of Wildlife Management, 53, $7-15$.

SAS Institute Inc. (1994) JMP Statistics and Graphics Guide. SAS Institute Inc., Cary, NC.

Sih, A., Crowley, P., McPeek, M., Petranka, J. \& Strohmeier, K. (1985) Predation, competition and prey communities: a review of field experiments. Annual Review of Ecology and Systematics, 16, 269-311.

Sinclair, A.R.E. (1989) Population regulation in animals Ecological Concepts (ed. J. M. Cherrett), pp. 197-241. Blackwell Scientific Publications, Oxford.

Sinclair, A.R.E. \& Pech, R.P. (1996) Density dependence, stochasticity, compensation and predator regulation. Oikos, 75, 164-173.

Sokal, R.R. \& Rohlf, F.J. (1981) Biometry. W.H. Freeman, San Francisco.

Statistical Sciences Inc. (1993) S-Plus. Windows Version 3.2 supplement. Seattle, Washington, U.S.A.

Stuart-Smith, A.K. \& Boutin, S. (1995) Predation on red squirrels during a snowshoe hare decline. Canadian Journal of Zoology, 73, 713-722.

Sullivan, T.P. (1990) Responses of red squirrel (Tamiasciurus hudsonicus)populations to supplemental food. Journal of Mammalogy, 71, 579-590.

Sullivan, T.P., Sullivan, D.S. \& Krebs, C.J. (1983) Demographic responses of a chipmunk (Eutamias townsendii) population with supplemental food. Journal of Animal Ecology, 52, 743-755.

Taitt, M.J. \& Krebs, C.J. (1981) The effect of extra food on small rodent populations. II. Voles (Microtus townsendii). Journal of Animal Ecology, 50, 125-137.

Taitt, M.J. \& Krebs, C.J. (1983) Predation, cover, and food manipulations during a spring decline of Microtus townsendii. Journal of Animal Ecology, 52, 837-848.

Tilman, D. (1989) Ecological experimentation: strengths and conceptual problems. Long-Term Studies in Ecology (ed. G. E. Likens), pp. 136-157. Springer-Verlag, New York.

Waterman, J.M. (1986) Behaviour and use of space by juvenile Columbian ground squirrels (Spermophilus columbianus). Canadian Journal of Zoology, 64, 1121-1127.

Watson, A. \& Moss, R. (1970) Dominance, spacing behavior, and aggression in relation to population limitation in vertebrates. Animal Populations in Relation to Their Food Resources (ed. A. Watson), pp. 167-220. Blackwell Scientific Publications, Oxford.

Wauters, L. \& Dhondt, A.A. (1989) Body weight, longevity and reproductive success in red squirrels (Sciurus vulgaris). Journal of Animal Ecology, 58, 637-651.

Winer, B.J. (1971) Statistical Principles in Experimental Design, 2nd edn. McGraw-Hill, New York, New York.

Zar, J.H. (1984) Biostatistical Analysis. Prentice-Hall, Inc., Englewood Cliffs, N

Received 19 June 1995; revision received 15 October 1996
(C) 1997 British

Ecological Society Journal of Animal

Ecology, 66, 527-541 